\title{
Nitroblue Tetrazolium Reduction of Neutrophils in Heat Stressed Goats Is Not Influenced by Selenium and Vitamin E Injection
}

\author{
Hiromu KATAMOTO, Hiroshi FUKUDA, Izumi OSHIMA ${ }^{1)}$, Naoto ISHIKAWA ${ }^{1)}$ and Yukio KANAI ${ }^{1)}$ \\ Department of Veterinary Surgery, College of Agriculture, Osaka Prefecture University, Sakai, Osaka 599-8531 and 'Institute of \\ Agriculture and Forestry, University of Tsukuba, Tsukuba-shi, Ibaraki 305-0006, Japan
}

(Received 17 March 1998/Accepted 19 July 1998)

\begin{abstract}
Experiment was designed to determine whether heat stress suppresses neutrophil function and injections of selenium and vitamin E prior to heat stress prevent suppression of neutrophil function in goats. Twelve female goats were divided into 2 groups of 6 each and were kept at $25^{\circ} \mathrm{C}$. Goats in the treatment group were injected intramuscularly with $0.1 \mathrm{mg} / \mathrm{kg}$ of selenium and $2.72 \mathrm{IU} / \mathrm{kg}$ of vitamin $\mathrm{E}$ at 8 and 1 day prior to the initiation of heat stress. The other group was kept as control. All goats were exposed to hot environment at $38^{\circ} \mathrm{C}$ from day 0 through 8 . Decreased tendency in plasma cortisol concentrations and temporary increase in plasma glucose concentrations were shown in both groups. In the control group, plasma selenium concentration gradually increased and $\alpha$ tocopherol concentration decreased during the first 2 days. After the second injection with selenium and vitamin E, plasma selenium and $\alpha$-tocopherol concentrations significantly increased and remained higher than those in the control group. Whole blood glutathione peroxidase (GSH-Px) activity in the treatment group tended to be greater than that in the control group, but no significant difference was observed between 2 groups. The nitroblue tetrazolium (NBT) reduction by activated neutrophils significantly decreased on day 6 in the control group but not in the treatment group. The NBT reduction by resting neutrophils significantly decreased in both groups. These data suggest that heat stress depresses neutrophil function, and selenium and vitamin E injection prior to heat stress has no apparent effect on neutrophil function during the stress. - KEY wORDS: heat stressed goat, neutrophil, nitroblue tetrazolium reduction, selenium, vitamin E.
\end{abstract}

J. Vet. Med. Sci. 60(11): 1243-1249, 1998

Heat stress suppresses immune function and increases susceptibility to infectious disease in food animals [19]. Elevated somatic cell counts and increased incidence of clinical mastitis occur in periods of high heat and humidity $[26,36]$. It is reported that serum corticosteroid levels increase during heat stress, and increased corticosteroids inhibit the function of neutrophils which are the main line of bovine host defense against intramammary infection [17]. In addition, decreased feed intake under the stress induces reduced intake of immunologically important micronutrients, including vitamin $\mathrm{A}$ and $\mathrm{E}$ and selenium [17]. The selenium (Se) containing enzyme, glutathione peroxidase (GSH-Px), and vitamin $\mathrm{E}$ are antioxidants protecting body cells and tissues from oxidative attack by free radicals, which are released during the respiratory burst associated with bacterial killing in neutrophils and macrophages [4]. The supplementation with selenium $[1,5,12]$, vitamin $\mathrm{E}[16$, $32]$ and the both $[14,15]$ has been shown to enhance the function of neutrophils in ruminants. Improvement in immune competence of stressed animals by nutritional manipulation, if possible, would be of a great value in animal production. However, little is known on selenium and vitamin $\mathrm{E}$ as well as the neutrophil function during heat stress in ruminants.

The purpose of this study was to determine whether heat stress suppresses neutrophil function and injections of selenium and vitamin E prior to heat stress prevent suppression of neutrophil function in goats.

\section{MATERIALS AND METHODS}

Animals: Twelve nonpregnant and nonlactating female Shiba goats, 3 to 5 years old, were used. Goats were randomly divided into 2 groups of 6 each and the mean $( \pm$ SEM) body weight was $22.3 \pm 1.3 \mathrm{~kg}$ in a treatment group and $25.2 \pm 1.1 \mathrm{~kg}$ in a control group. Eleven days prior to the initiation of heat stress, 2 groups of animals were moved to climatic chambers at $25^{\circ} \mathrm{C}, 50 \%$ relative humidity and 12 $\mathrm{hr}$ light/dark cycle. Goats were fed an alfalfa hay containing $0.037 \mathrm{mg} / \mathrm{kg}$ of selenium and $33.9 \mathrm{mg} / \mathrm{kg}$ of $\alpha$-tocopherol on a dry matter (DM) basis. Water and a trace mineral salt containing no selenium were available ad libitum.

Experimental procedures: Goats in a treatment group were injected intramuscularly with $0.1 \mathrm{mg} / \mathrm{kg}$ of selenium and $2.72 \mathrm{IU} / \mathrm{kg}$ of vitamin $\mathrm{E}\left(\mathrm{E}-\mathrm{SE}^{\circledR}\right.$, Schering-Plough Animal Health, Union, NJ) at 8 and 1 day prior to the initiation of heat stress. Goats in a control group were injected with equal volume of $2 \%$ benzyl alcohol which was contained in $\mathrm{E}_{-\mathrm{SE}}{ }^{\circledR}$ as a preservative. After 11 days of adaptation, the chamber temperature was increased at 10:00 on day 0 up to $38^{\circ} \mathrm{C}$ at the rate of $1^{\circ} \mathrm{C}$ per hr, but the relative humidity and lighting remained unchanged. These conditions were maintained through day 8. Blood samples were collected from jugular vein using heparinized vacuum tubes at 9:00 on day $-8,-1,0,1,2,3,4,6$ and 8 . Rectal temperature and respiration rate were recorded after blood sampling. Hematocrit and white blood cell count were 
determined using a particle counter (Model MEK-6108, Nihon Kohden Corp., Tokyo, Japan). Whole blood and plasma were stored at $-80^{\circ} \mathrm{C}$ until analyzed.

Isolation of neutrophils: Three $\mathrm{m} l$ of blood was diluted with $3 \mathrm{ml}$ of RPMI 1640 medium (Gibco, Grand Island, $\mathrm{NY}$ ) containing $1.5 \mathrm{mg} / \mathrm{m} l$ of disodium EDTA and layered over $60 \%$ Percoll $^{\circledR}$ (Pharmacia, Uppsala, Sweden). After centrifugation at $500 \times \mathrm{g}$ for $25 \mathrm{~min}$ at $20^{\circ} \mathrm{C}$, the supernatant was removed by aspiration and the packed erythrocyte layer was suspended in $5 \mathrm{ml}$ of Hanks' balanced salt solution (HBSS, pH 7.2). The cell suspension was centrifuged at $400 \times \mathrm{g}$ for $20 \mathrm{~min}$ at $4^{\circ} \mathrm{C}$, the supernatant was discarded, and remaining erythrocytes were lysed by the addition of 10 $\mathrm{ml}$ of buffered $0.15 \mathrm{M}$ ammonium chloride containing 17 $\mathrm{mM}$ tris with gentle mixing at $37^{\circ} \mathrm{C}$. The cell pellet obtained after centrifugation at $400 \times \mathrm{g}$ for $7.5 \mathrm{~min}$ at $4^{\circ} \mathrm{C}$ was washed twice with HBSS and suspended in RPMI 1640 medium. Viable cells were determined by trypan blue exclusion and counted with a Bürker-Türk counting chamber. The purity of neutrophils was $95.9 \%$. The final cell concentrations were adjusted to $5.0 \times 10^{6}$ viable cells/ $\mathrm{m} l$ of RPMI 1640 medium.

Nitroblue tetrazolium (NBT) reduction test: NBT reduction by neutrophils was evaluated by a modification of the procedure of Murata et al. [28]. Tests were conducted in duplicate in $15 \times 105 \mathrm{~mm}$ silicon-coated glass tubes. The NBT solution was prepared by suspending NBT (Sigma Chemical Co., St. Louis, MO) in RPMI 1640 medium at a concentration of $1 \mathrm{mg} / \mathrm{m} l$. Insoluble NBT was removed by filtration. After zymosan A (Sigma Chemical Co.) suspended in distilled water was dipped in boiling water for $30 \mathrm{~min}$, the suspension was centrifuged at $250 \times \mathrm{g}$ for 10 min, and the supernatant was discarded. Opsonized zymosan A was prepared by suspending zymosan A in fresh goat serum at a concentration of $25 \mathrm{mg} / \mathrm{ml}$ and incubating at $37^{\circ} \mathrm{C}$ with shaking for $30 \mathrm{~min}$. The mixture was centrifuged at $250 \times \mathrm{g}$ for $10 \mathrm{~min}$, and the supernatant was discarded. The pellet was resuspended in RPMI 1640 medium and frozen at $-80^{\circ} \mathrm{C}$. The reaction mixture consisted of $0.5 \mathrm{~m} l$ of cell suspension $\left(5.0 \times 10^{6} / \mathrm{ml}\right), 0.4 \mathrm{ml}$ of the NBT solution and $0.1 \mathrm{~m} l$ of opsonized zymosan A suspension $(10 \mathrm{mg} / \mathrm{ml})$. Reduction of NBT by resting cells was determined in a similar set of tubes in which opsonized zymosan A was omitted. After incubation at $37^{\circ} \mathrm{C}$ for 30 min, the reaction was terminated by adding $1.0 \mathrm{~m} l$ of $0.5 \mathrm{~N}$ $\mathrm{HCl}$. The mixture then was centrifuged at $1,000 \times \mathrm{g}$ for 10 min, and the supernatant was discarded. The precipitate was dissolved with $3 \mathrm{ml}$ of dimethyl sulfoxide (DMSO), heated in boiling water for $5 \mathrm{~min}$ and cooled. After the mixture was clarified by centrifugation at $500 \times \mathrm{g}$ for 5 min, the optical density at $565 \mathrm{~nm}$ was determined immediately using a DMSO blank. Results were expressed as a percent of the value on day -1 .

Chemical analyses: Plasma selenium concentrations were determined by a modification of the method of Bayfield and Romalis [2]. The plasma $(0.1 \mathrm{ml})$ was digested with $0.5 \mathrm{ml}$ of $60 \%$ nitric acid and $1.0 \mathrm{ml}$ of $0.75 \mathrm{~N}$ perchloric acid at $100^{\circ} \mathrm{C}$ for $2 \mathrm{hr}$ and at $160^{\circ} \mathrm{C}$ for $4 \mathrm{hr}$, and reduced with 0.5 $\mathrm{m} l$ of $6 \mathrm{~N} \mathrm{HCl}$ at $160^{\circ} \mathrm{C}$ for $1 \mathrm{hr}$. After cooling, $1.0 \mathrm{ml}$ of $0.1 \mathrm{M}$ citrate buffer, $\mathrm{pH} 1.42$, and $0.2 \mathrm{ml}$ of $20 \mathrm{mM}$ EDTA$2 \mathrm{Na}$ were added and the $\mathrm{pH}$ was adjusted to 1.42 with $5 \%$ $\mathrm{NH}_{4} \mathrm{OH}$. In the dark, the piazselenol complex was formed by adding $0.5 \mathrm{~m} l$ of $0.1 \%$ 2,3-diaminonaphthalene (DAN) in $0.1 \mathrm{~N} \mathrm{HCl}$ and incubating at $50^{\circ} \mathrm{C}$ for $15 \mathrm{~min}$. After extraction with cyclohexane, the fluorescence was measured at $520 \mathrm{~nm}$ using excitation wavelength of $377 \mathrm{~nm}$. Whole blood GSH-Px activity was determined by the method of Paynter [31]. Hemoglobin (Hb) concentrations were assayed by Hemoglobin-Test kit (Wako Pure Chemical Industries Ltd., Osaka, Japan) and activity units (EU) were expressed as $\mu \mathrm{mol}$ of NADPH oxidized per min per $\mathrm{g}$ of $\mathrm{Hb}$ at $25^{\circ} \mathrm{C}$. Plasma $\alpha$-tocopherol was analyzed by high performance liquid chromatography (HPLC) using a modification of the procedure of Mino et al. [23]. Briefly, $0.5 \mathrm{ml}$ of plasma was placed into a centrifuge tube together with $0.5 \mathrm{~m} l$ of

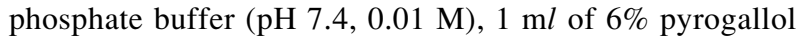
solution in ethanol and $1 \mathrm{ml}$ of 2,2,5,7,8-pentamethyl-6hydroxychroman solution $(2 \mu \mathrm{g} / \mathrm{m} l$ ethanol, Wako Pure Chemical Industries Ltd.) as an internal standard, and preincubated for $2 \mathrm{~min}$ at $70^{\circ} \mathrm{C}$. After preincubation, 0.2 $\mathrm{m} l$ of $60 \% \mathrm{KOH}$ was added to the solution mixture, and the samples were saponified at $70^{\circ} \mathrm{C}$ for $30 \mathrm{~min}$. After cooling, $2.5 \mathrm{ml}$ of water and $5 \mathrm{ml}$ of hexane were added to the tube, which was vigorously shaken for $5 \mathrm{~min}$. The mixture was centrifuged at 1,000 rpm for $5 \mathrm{~min}$ and $3 \mathrm{ml}$ of the hexane layer was removed and evaporated under nitrogen at $37^{\circ} \mathrm{C}$. The residue was dissolved in $0.8 \mathrm{~m} l$ of ethanol and filtered through Cosmonice Filter S (pore size $0.5 \mu \mathrm{m}$, Nacalai Tesque, Inc., Kyoto, Japan), and $40 \mu l$ was injected into the HPLC column. The instruments used in this assay were as follows: the HPLC equipment was a Shimadzu LC-6A (Shimadzu Co., Ltd., Kyoto) with a Resolve C18 $3.9 \times 150$ mm column (Nihon Millipore Ltd., Tokyo). The eluent was methanol and the flow rate was $0.9 \mathrm{ml} / \mathrm{min}$, and the detector was a Shimadzu RF-535 fluorospectrophotometer (Ex 295 nm, Em $325 \mathrm{~nm}$ ). Plasma glucose concentrations were determined by Glucose-Test kit (Wako Pure Chemical Industries Ltd.). Plasma cortisol concentrations were measured by using a commercially available radioimmunoassay kit (DPC Cortisol kit, Diagnostic Products Corporation, Los Angeles, CA).

Statistical analysis: Data were analyzed by two-way repeated measures ANOVA. Differences between sampling days within a treatment and between treatment groups within a sampling period were tested by paired and unpaired Student's $t$-test, respectively.

\section{RESULTS}

Animal condition: Under heat stress, animals showed depression, increased respiration rate, open-mouthed breathing and decreased feed intake. Daily food intake decreased by $14 \%$ and $30 \%$ in the control group and the treatment group, respectively. The rectal temperature and 
Table 1. Effects of heat stress on rectal temperature, respiration rate, hematocrit and white blood cell count

\begin{tabular}{llccc}
\hline & & \multicolumn{3}{c}{ Days after the onset of heat stress } \\
\cline { 3 - 5 } Parameter & Groups & Day 0 & Day 1 & Day 8 \\
\hline \multirow{2}{*}{ Rectal temperature } & Control & $38.6 \pm 0.1$ & $39.9 \pm 0.1^{* * *}$ & $40.0 \pm 0.1^{* * *}$ \\
$\left({ }^{\circ} \mathrm{C}\right)$ & Treatment & $38.7 \pm 0.1$ & $40.1 \pm 0.1^{* * *}$ & $39.8 \pm 0.3^{* *}$ \\
Respiration rate & Control & $38 \pm 3$ & $231 \pm 10^{* * *}$ & $163 \pm 12^{* * *}$ \\
(per min) & Treatment & $31 \pm 2$ & $227 \pm 6^{* * *}$ & $169 \pm 11^{* * *}$ \\
Hematocrit $(\%)$ & Control & $29.1 \pm 1.7$ & $29.5 \pm 1.0$ & $27.4 \pm 1.7$ \\
& Treatment & $28.6 \pm 1.5$ & $28.1 \pm 1.4$ & $25.3 \pm 1.1^{*}$ \\
White blood cell count & Control & $8350 \pm 205$ & $7761 \pm 185$ & $8603 \pm 936$ \\
$($ per $\mu l)$ & Treatment & $8117 \pm 570$ & $7778 \pm 867$ & $7797 \pm 533$ \\
\hline
\end{tabular}

Data represent the mean \pm SEM of 6 goats per group. *,**,*** Significantly differs from the value on day 0 at $\mathrm{P}<0.05, \mathrm{P}<0.01$ and $\mathrm{P}<0.001$, respectively.

respiration rate in both groups significantly $(\mathrm{P}<0.01$ to 0.001 ) increased following heat stress (Table 1). The values of hematocrit in the treatment group slightly decreased $(\mathrm{P}<0.05)$ on day 8 , but white blood cell counts in both groups were not affected by heat stress. The effect of selenium and vitamin $\mathrm{E}$ injection on these parameters was not significant.

Plasma cortisol and glucose levels: As time progressed, plasma cortisol concentrations in both groups of animals decreased (Fig. 1). The concentrations on day 3 and 6 in the treatment group were lower $(\mathrm{P}<0.05)$ than the level on day - 1 . The both groups showed decreased tendency in plasma glucose concentrations from day -1 to day 0 . Plasma glucose concentrations significantly increased on day $2(\mathrm{P}<0.01)$ in the treatment group and on day $3(\mathrm{P}<0.05)$ in the control group compared with their values on day 0 , and then began to decline. Mean values of both groups returned to their levels on day 0 at the end of the study. Selenium and vitamin $E$ injection had no effect on the concentrations of cortisol and glucose in plasma.

Plasma selenium level and blood GSH-Px activity: Mean $( \pm$ SEM) plasma selenium concentrations were $46.9 \pm 5.4$ and $61.1 \pm 11.4 \mathrm{ng} / \mathrm{m} l$ in the control and treatment group, respectively, on day -8 prior to the first injection. Goats injected with selenium and vitamin $\mathrm{E}$ had greater $(\mathrm{P}<0.001)$ plasma selenium concentration than control animals on day -1 (Fig. 2). After the second injection, the concentration significantly $(\mathrm{P}<0.01)$ increased and higher $(\mathrm{P}<0.001)$ level was maintained during the study period. The concentration in the control animals gradually increased $(\mathrm{P}<0.05)$ following heat stress. Whole blood GSH-Px activity in the treatment group tended to increase and that in the control group tended to decline under heat stress. There was no significant difference in whole blood GSH-Px activity between 2 groups throughout the study.

Plasma $\alpha$-tocopherol level: Mean $( \pm$ SEM) plasma $\alpha$ tocopherol concentrations were $358.0 \pm 35.9$ and $317.3 \pm$ $33.3 \mu \mathrm{g} / \mathrm{d} l$ in the control and treatment group, respectively, on day -8 prior to the first injection. Goats injected with selenium and vitamin $\mathrm{E}$ had greater $(\mathrm{P}<0.05)$ plasma $\alpha$ tocopherol concentration than control animals on day -1

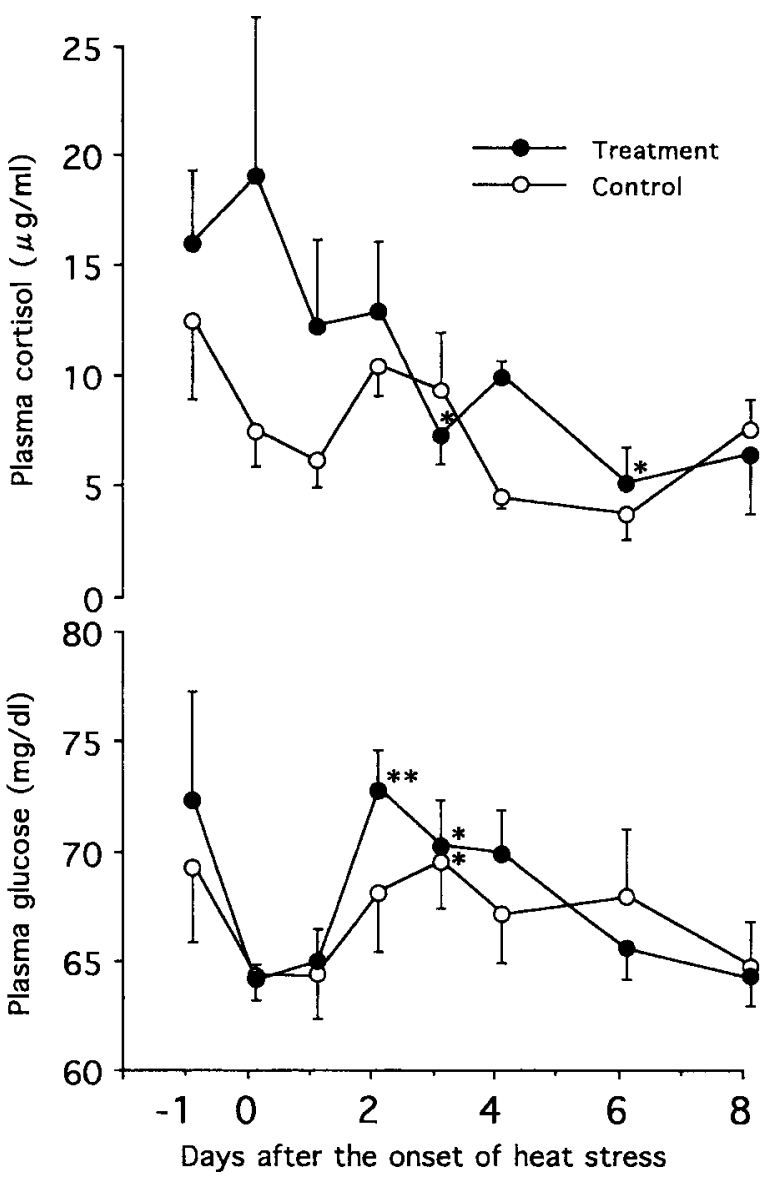

Fig. 1. Mean ( \pm SEM) plasma cortisol and glucose concentrations in goats. Goats in treatment group $(n=6)$ were injected with $0.1 \mathrm{mg} / \mathrm{kg}$ of selenium and $2.72 \mathrm{IU} / \mathrm{kg}$ of vitamin $\mathrm{E}$ intramuscularly on day -8 and -1 . Goats in control group $(\mathrm{n}=6)$ received a placebo. $* * *$ Significantly differs from the value on day -1 (on day 0 in glucose) at $\mathrm{P}<0.05$ and $\mathrm{P}<0.01$, respectively. 


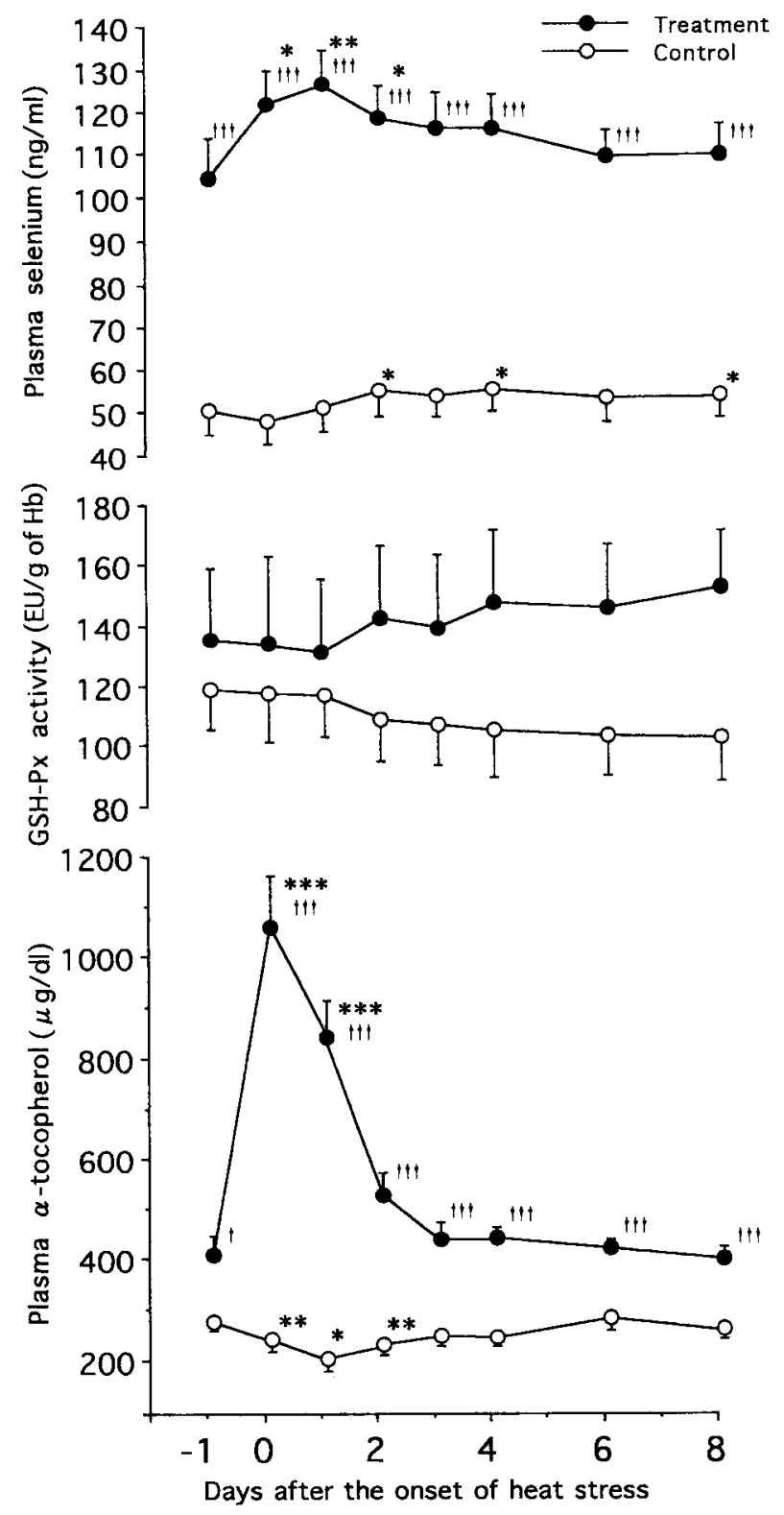

Fig. 2. Mean ( \pm SEM) plasma selenium concentration, whole blood GSH-Px activity and plasma $\alpha$-tocopherol concentration in goats. Goats in treatment group $(n=6)$ were injected with $0.1 \mathrm{mg} / \mathrm{kg}$ of selenium and $2.72 \mathrm{IU} / \mathrm{kg}$ of vitamin $\mathrm{E}$ intramuscularly on day -8 and -1 . Goats in control group $(\mathrm{n}=6)$ received a placebo. $*, * *, * * *$ Significantly differs from the value on day -1 at $\mathrm{P}<0.05, \mathrm{P}<0.01$ and $\mathrm{P}<0.001$, respectively. $\dagger, \dagger+\dagger$ Significantly differs from the value in control group within a sampling period at $\mathrm{P}<0.05$ and $\mathrm{P}<0.001$, respectively.

(Fig. 2). After the second injection, the concentration significantly $(\mathrm{P}<0.001)$ increased on day 0 and then began to decline through day 3 , but greater $(\mathrm{P}<0.001)$ level was maintained through day 8 . The concentration in the control animals significantly $(\mathrm{P}<0.05)$ declined during the first 2 days of heat stress.

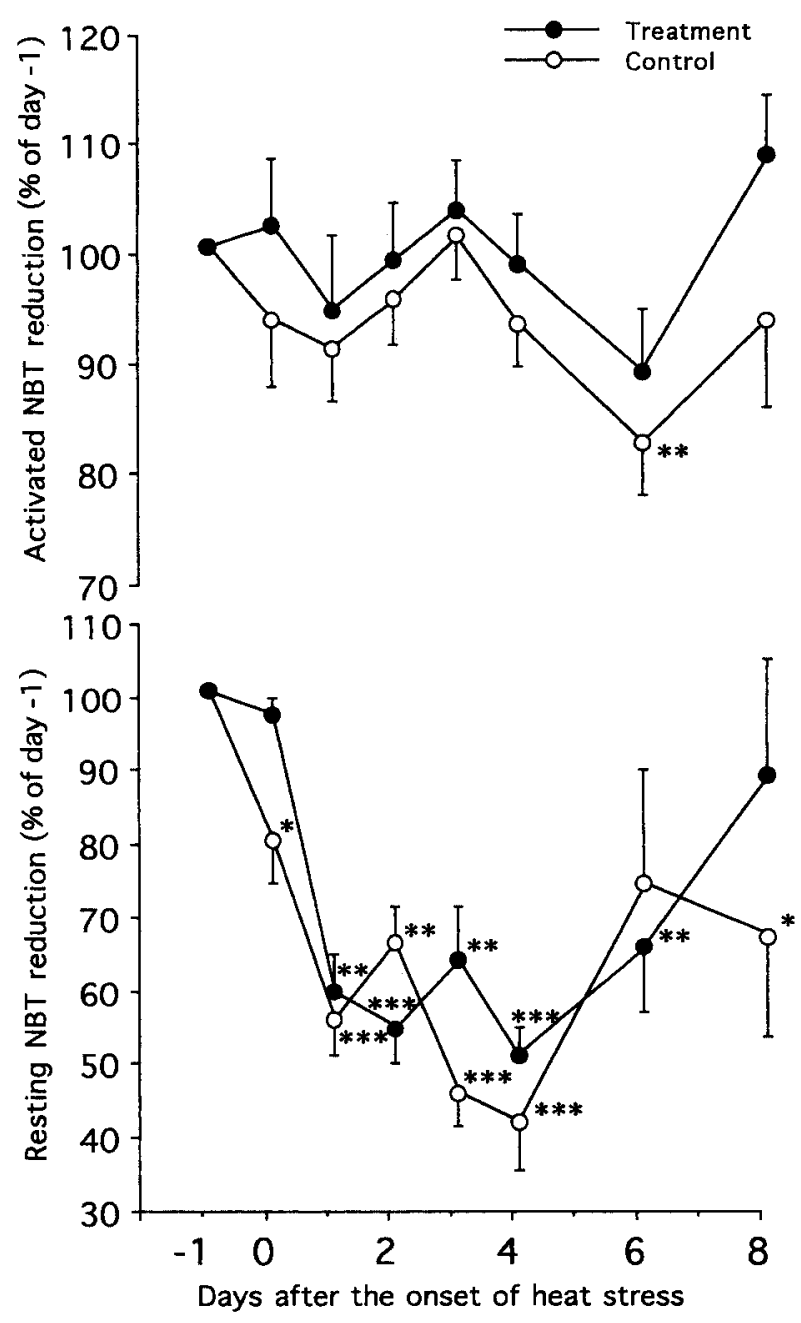

Fig. 3. Mean $( \pm$ SEM) percent of NBT reduction by activated and resting neutrophils from goats. Results are expressed as relative changes to the value on day -1 . Goats in treatment group $(\mathrm{n}=6)$ were injected with $0.1 \mathrm{mg} / \mathrm{kg}$ of selenium and $2.72 \mathrm{IU} / \mathrm{kg}$ of vitamin E intramuscularly on day -8 and -1 . Goats in control group $(\mathrm{n}=6)$ received a placebo. $*, * *, * * *$ Significantly differs from the value on day -1 at $\mathrm{P}<0.05$, $\mathrm{P}<0.01$ and $\mathrm{P}<0.001$, respectively.

NBT reduction by neutrophils: In both groups, the NBT reduction by activated neutrophils was influenced by heat stress in a similar pattern (Fig. 3). The NBT reduction in the control group significantly $(\mathrm{P}<0.01)$ decreased on day 6 but not in the treatment group. The NBT reduction by resting neutrophils significantly $(\mathrm{P}<0.001)$ decreased in both groups under heat stress. The effect of selenium and vitamin E injection on NBT reduction was not significant.

\section{DISCUSSION}

The NBT reduction by activated and resting neutrophils in both groups was suppressed under heat stress. The NBT reduction test is a measure of the ability of neutrophils to 
produce superoxide anion by the respiratory burst, providing information on both phagocytic and bactericidal activities [34]. In cattle, in vivo heat stress had no significant effect on responses of polymorphonuclear leukocytes (PMNL), but in vitro heat stress reduced responses of PMNL and lymphocytes [8]. In addition, heat stress decreased lymphoid cell proliferation and synthesis of antibodies in rabbits [10]. Regardless of the nature of stress, physical or psychological, one of the final common pathways is the stimulation of adrenocortical secretion, with consequent increase in serum glucocorticoids, which are known to heavily inhibit immune cell functions $[6,13]$. In the present study, neutrophil function was depressed under heat stress, whereas plasma cortisol levels tended to decrease. These findings indicate that glucocorticoids cannot account fully for the negative effects of stress on functions of cells of the immune system as proposed in stressed lambs [25]. Depressed NBT reduction in both groups tended to return to pretreatment value from day 6 through 8 . These recoveries from stress may be associated with compensatory physiological processes, e.g. antioxidant systems [10]. The recovery of immune cell functions has been reported in heat stressed rabbits [10].

Although plasma selenium and $\alpha$-tocopherol levels in the treatment group remained significantly greater than those in the control group during heat stress, no significant difference in NBT reduction was found between 2 groups. The immunostimulatory effects of selenium and vitamin $\mathrm{E}$ have been widely recognized in domestic animals [9]. A decrese in microbicidal activity and NBT reduction has been reported in the neutrophils of selenium-deficient steers [5]. In addition, vitamin $\mathrm{E}$ supplementation prevented suppression of superoxide production by bovine blood neutrophils observed in early lactation [32]. The respiratory burst by neutrophils is characterized by marked changes in oxygen metabolism that result in increased production of superoxide and hydrogen peroxide [4]. Although neutrophilgenerated oxygen metabolites are necessary in antimicrobial defense mechanisms, these free radicals can also damage the neutrophil and surrounding tissues [4]. The selenium containing enzyme GSH-Px can protect neutrophils by detoxifying peroxides in the cytosol and vitamin $\mathrm{E}$ inhibits autoxidation of polyunsaturated fatty acids in neutrophil membranes, and the both enhance neutrophil function [4]. One of the reasons for no beneficial effect of selenium and vitamin $\mathrm{E}$ injection may be related to insufficient period in which goats received selenium and vitamin $E$ supplementation prior to heat stress, because GSH-Px activity in the treatment group was not significantly higher than that in the control group. When the NBT reduction by activated neutrophils was compared with the value on day -1 , significant decrease was observed in the control group but not in the treatment group. These findings may suggest a possibility that selenium and vitamin E supplementation is a means to minimize the depression in neutrophil function during heat stress.

Acute stressors activate the hypothalamo-pituitary-adrenal axis, resulting ultimately in increased serum cortisol concentrations in farm animals [6]. In addition, adrenal corticosteroids are known to have immunosuppressive actions [13]. In the present study, plasma cortisol concentrations in both groups tended to decline under heat stress for 8 days as reported previously in ewes [3] and calves [35]. On the contrary, serum cortisol concentrations elevated rapidly and returned to pretreatment concentrations within $12 \mathrm{hr}$ after the onset of heat stress in lambs [24]. These different observations suggest that short-term heat stress evokes transient increase in serum cortisol levels, whereas long-term heat stress results in reduced serum cortisol levels. The changes in cortisol levels caused by long-term heat stress may reflect adaptive changes in tissue calorigenesis [3]. Moreover, the pattern of cortisol secretion in response to heat stress may depend on several factors such as the differences in animal species, thermal manipulations, the intensity or duration of heat stress and the frequency of blood sampling. It was reported that vitamin E long-term oral supplementation decreased serum corticosteroid levels in mice [20] and calves [33]. The protective effects of vitamin $\mathrm{E}$ on the immune system were partially explained by reduced circulating levels of glucocorticoids [11]. In the present study, selenium given at therapeutic dose in selenium deficiency cattle [22] and vitamin E injection did not affect plasma cortisol levels. This observation was consistent with the previous findings that vitamin E injection did not affect plasma cortisol levels in surgically stressed cows [27].

Plasma glucose concentrations increased in goats of both groups. This increase in plasma glucose levels may be controlled by elevation of plasma catecholamine levels, since increased plasma catecholamine levels have been observed in heat stressed goats [18].

Although selenium and vitamin $\mathrm{E}$ injection resulted in twofold increase in plasma selenium concentration relative to that in the control group, whole blood GSH-Px activity was not different between the treatment and control group. In cattle, the increase in blood GSH-Px activity occurred approximately 28 days after selenium injection [21]. The incorporation of selenium into erythrocyte GSH-Px, which is the major contributor to blood GSH-Px activity, occurs in the bone marrow [21]. The life span of erythrocytes in adult cattle is approximately 160 days, and circulating erythrocytes do not retain the ability to incorporate selenium into GSH-Px, and thus a lag time would be expected [21]. The present study also indicates that more than 16 days are required before GSH-Px activity would increase.

In the control group, slight increase in plasma selenium level, reduced tendency in GSH-Px activity and temporary decrease in $\alpha$-tocopherol level were observed. The reason for this increased selenium level is not clear. The changes in GSH-Px activity and $\alpha$-tocopherol level may suggest that heat stress affects cellular antioxidants. It has been suggested that stress may increase metabolic rate and subsequent oxygen radical production [7]. Cattle that were stressed by restricted food intake followed by ACTH and 
epinephrine injection showed reduced $\alpha$-tocopherol concentrations in erythrocytes and liver [29].

Heat stress did not influence white blood cell count but brought reduction in the value of hematocrit in the treatment group on day 8. This decline in hematocrit may be due to an increase in water consumption and an increased plasma volume during heat stress [30].

In conclusion, plasma cortisol concentrations tended to decrease, whereas neutrophil function was suppressed under heat stress. Selenium and vitamin E injection had no effect on cortisol concentrations and neutrophil function. More studies are required to establish beneficial effects of selenium and vitamin $\mathrm{E}$ in ruminants under heat stress.

\section{REFERENCES}

1. Aziz, E. S., Klesius, P. H. and Frandsen, J. C. 1984. Effects of selenium on polymorphonuclear leukocyte function in goats. Am. J. Vet. Res. 45: 1715-1718.

2. Bayfield, R. F. and Romalis, L. F. 1985. pH control in the fluorometric assay for selenium with 2,3-diaminonaphthalene. Anal. Biochem. 144: 569-576.

3. Bell, A. W., McBride, B. W., Slepetis, R., Early, R. J. and Currie, W.B. 1989. Chronic heat stress and prenatal development in sheep: 1. Conceptus growth and maternal plasma hormones and metabolites. J. Anim. Sci. 67: 3289-3299.

4. Bendich, A. 1990. Antioxidant micronutrients and immune responses. Ann. New York Acad. Sci. 587: 168-180.

5. Boyne, R. and Arthur, J. R. 1979. Alterations of neutrophil function in selenium-deficient cattle. J. Comp. Pathol. 89: 151-158.

6. Dantzer, R. and Mormède, P. 1983. Stress in farm animals: A need for reevaluation. J. Anim. Sci. 57: 6-18.

7. Duthie, G. G., Arthur, J. R., Nicol, F. and Walker, M. 1989. Increased indices of lipid peroxidation in stress-susceptible pigs and effects of vitamin E. Res. Vet. Sci. 46: 226-230.

8. Elvinger, F., Hansen, P. J. and Natzke, R. P. 1991. Modulation of function of bovine polymorphonuclear leukocytes and lymphocytes by high temperature in vitro and in vivo. Am.J. Vet. Res. 52: 1692-1698.

9. Finch, J. M. and Turner, R. J. 1996. Effects of selenium and vitamin $\mathrm{E}$ on the immune responses of domestic animals. Res. Vet. Sci. 60: 97-106.

10. Franci, O., Amici, A., Margarit, R., Merendino, N. and Piccolella, E. 1996. Influence of thermal and dietary stress on Immune response of rabbits. J. Anim. Sci. 74: 1523-1529.

11. Frye, T. M., Williams, S. N. and Graham, T. W. 1991. Vitamin deficiencies in cattle. Vet. Clin. North Am. Food Anim. Pract. 7: 217-275.

12. Grasso, P. J., Scholz, R. W., Erskine, R. J. and Eberhart, R. J. 1990. Phagocytosis, bactericidal activity, and oxidative metabolism of milk neutrophils from dairy cows fed selenium-supplemented and selenium-deficient diets. Am. J. Vet. Res. 51: 269-274.

13. Griffin, J. F. T. 1989. Stress and immunity: A unifying concept. Vet. Immunol. Immunopathol. 20: 263-312.

14. Gyang, E. O., Stevens, J. B., Olson, W. G., Tsitsamis, S. D. and Usenik, E. A. 1984. Effects of selenium-vitamin E injection on bovine polymorphonucleated leukocytes phagocytosis and killing of Staphylococcus aureus. Am. J. Vet. Res. 45: $175-177$.
15. Hogan, J. S., Smith, K. L., Weiss, W. P., Todhunter, D. A. and Schockey, W. L. 1990. Relationships among vitamin E, selenium, and bovine blood neutrophils. J. Dairy Sci. 73: 2372-2378.

16. Hogan, J. S., Weiss, W. P., Todhunter, D. A., Smith, K. L. and Schoenberger, P. S. 1992. Bovine neutrophil responses to parenteral vitamin E. J. Dairy Sci. 75: 399-405.

17. Jacobsen, K. L. 1996. The well-being of dairy cows in hot and humid climates. Part I. Housing and effects of heat stress. Compend. Contin. Educ. Pract. Vet. 18: (Suppl.) S137-S143.

18. Katti, P., Johnson, H. D. and Niwano, Y. 1991. Hormonal profiles of African Pygmy goats exposed to heat environment. Anim. Sci. Technol. (Jpn.) 62: 12-17.

19. Kelly, K. W. 1985. Immunological consequences of changing environmental stimuli. pp. 193-223. In: Animal Stress (Moberg, G. P. ed.), American Physiological Society, Bethesda, MD.

20. Lim, T. S., Putt, N., Safranski, D., Chung, C. and Watson, R. R. 1981. Effect of vitamin E on cell-mediated immune responses and serum corticosterone in young and maturing mice. Immunology 44: 289-295.

21. Maas, J., Peauroi, J. R., Tonjes, T., Karlonas, J., Galey, F. D. and Han, B. 1993. Intramuscular selenium administration in selenium-deficient cattle. J. Vet. Intern. Med. 7: 342-348.

22. McCaughan, C. J. 1992. Treatment of mineral disorders in cattle. Vet. Clin. North Am. Food Anim. Pract. 8: 107-145.

23. Mino, M., Kitagawa, M. and Nakagawa, S. 1985. Red blood cell tocopherol concentrations in a normal population of Japanese children and premature infants in relation to the assessment of vitamin E status. Am. J. Clin. Nutr. 41: 631638.

24. Minton, J. E. and Blecha, F. 1990. Effect of acute stressors on endocrinological and immunological functions in lambs. J. Anim. Sci. 68: 3145-3151.

25. Minton, J. E., Apple, J. K., Parsons, K. M. and Blecha, F. 1995. Stress-associated concentrations of plasma cortisol cannot account for reduced lymphocyte function and changes in serum enzymes in lambs exposed to restraint and isolation stress. J. Anim. Sci. 73: 812-817.

26. Morse, D., DeLorenzo, M. A., Natzke, R. P. and Bray, D. R. 1988. Characterization of clinical mastitis records from one herd in a subtropical environment. J. Dairy Sci. 71: 13961405.

27. Mudron, P., Scholz, H., Sallmann, H. P., Rehage, J., Kovac, G., Bartko, F. and Höltershinken, M. 1994. Effect of vitamin $\mathrm{E}$ injection on cortisol and white blood cell response to surgical stress in dairy cows. Int. J. Vitam. Nutr. Res. 64: 176-180.

28. Murata, H., Takahashi, H. and Matsumoto, H. 1987. The effects of road transportation on peripheral blood lymphocyte subpopulations, lymphocyte blastogenesis and neutrophil function in calves. Br. Vet. J. 143: 166-174.

29. Nockels, C. F., Odde, K. G. and Craig, A. M. 1996. Vitamin E supplementation and stress affect tissue $\alpha$-tocopherol content of beef heifers. J. Anim. Sci. 74: 672-677.

30. Paape, M. J., Schultze, W. D., Miller, R. H. and Smith, J. W. 1973. Thermal stress and circulating erythrocytes, leucocytes, and milk somatic cells. J. Dairy Sci. 56: 84-91.

31. Paynter, D. I. 1979. Glutathione peroxidase and selenium in sheep. I Effect of intraruminal selenium pellets on tissue glutathione peroxidase activities. Aust. J. Agr. Res. 30: 695-702.

32. Politis, I., Hidiroglou, M., Batra, T. R., Gilmore, J. A., Gorewit, R. C. and Scherf, H. 1995. Effects of vitamin E on immune function of dairy cows. Am. J. Vet. Res. 56: 179- 
184.

33. Reddy, P. G., Morrill, J. L., Minocha, H. C. and Stevenson, J. S. 1987. Vitamin E is immunostimulatory in calves. J. Dairy Sci. 70: 993-999.

34. Roth, J. A. and Kaeberle, M. L. 1981. Evaluation of bovine polymorphonuclear leukocyte function. Vet. Immunol. Immunopathol. 2: 157-174.
35. Takahashi, H., Murata, H. and Matsumoto, H. 1986. Secretory responses of plasma insulin, glucagon, cortisol and glucose to heat exposure in calves. Jpn. J. Vet. Sci. 48: 1287 1289.

36. Wegner, T. N., Schuh, J. D., Nelson, F.E. and Stott, G. H. 1976. Effect of stress on blood leucocyte and milk somatic cell counts in dairy cows. J. Dairy Sci. 59: 949-956. 